J. Perinat. Med. 6 (1978) 240

\title{
Inhibition of fetal lung maturation by indomethacin in pregnant rabbits
}

\author{
Raúl Bustos, Gustavo Ballejo, Gustavo Giussi, Rafael Rosas, Julio C. Isa
}

Latin American Center of Perinatology and Human Development Pan American Health Organization/World Health Organization, Montevideo, Uruguay

It has been previously shown that maternal or fetal administration of steroids induces fetal lung maturation in certain animal species $[3,7,13,15]$.

Studies by LIGGINS and HowIE [12] have demonstrated an acceleration of fetal lung maturation in humans following the parenteral administration of betamethasone (a corticosteroid) to women 48-72 hours before delivery, evidenced by a reduction in the incidence of respiratory distress syndrome (RDS) in these infants.

On the other hand, it has been suggested that maternal administration of Indomethacin can produce uterine inhibition in humans when the pregnant woman starts a premature labor [22]. VANE [20] demonstrated that Indomethacin simultaneously inhibited prostaglandins (PGs) release and spontaneous contractions of pregnant rat uteri in vitro.

The role of PGs in parturition is suggested by the observed increase of PGs concentration in human blood [10] and amniotic fluid [9] during labor and by the observation that exogenously administered PGs can induce labor [11] or abortion [17].

Since PGs are involved in many metabolic processes, we have studied the action of Indomethacin given to pregnant rabbits, on fetal lung maturation.

\section{Material and methods}

Thirty four time-dated pregnant Californian rabbits (14 control and 20 Indomethacin-treated animals) were used in this study. They were mated between 10 am and $2 \mathrm{pm}$, so that gestational age could be calculated arbitrarily to within 4 hours.

Experimental procedures were performed at the same hours.

The does were treated three days before delivery, with $\mathrm{i} / \mathrm{m}$ administration of Indomethacin $(10 \mathrm{mg} /$ $\mathrm{kg} /$ day) or solvent (placebo) twice daily, until delivery (e.g. those delivered on the 27 th day of gestation received treatment from day 24).

The rabbits were fed ad libitum with water and rabbit food.Daily observations were made to assure that Indomethacin-treated animals were in good condition. No obvious difference was observed between both groups.

The fetuses were delivered by hysterotomy at 27 , 28,29 and 30 days of gestation, using $i / v$ penthobarbital. The time between penthobarbital injection and hysterotomy was about 1-2 minutes. No fetal wastage was observed.

The newborns were allowed to breathe room air placed in an incubator at $37^{\circ} \mathrm{C}$, for 30 minutes before they were weighed. At this time, they were killed with $30 \mathrm{mg}$ of intra-peritoneal sodium penthobarbital. Exsanguination by cutting the abdominal aorta and tracheostomy was performed in five newborns of the litter.

Once tracheostomized, lung washes were performed as follows. Each pair of lungs was gently expanded with air from a syringe connected to the trachea by a polyethylene tube. This was followed by five gentle lavagings, each with $2 \mathrm{ml}$ of 0.9 saline 
$\left(20^{\circ} \mathrm{C}\right)$. The washings which totalled $10 \mathrm{ml}$ for each pair of lungs were pooled by litter groups and the cells and debris in the lavage fluid removed by centrifugation (1000 xg, $5 \mathrm{~min}$ ).

After the lavages, the lungs were dried in a desiccator at $100^{\circ} \mathrm{C}$ until their weight was constant for the purpose of unit expression of alveolar wash phospholipid content.

The blood collected after exsanguination of the newborns was pooled by litter groups, allowed to coagulate and Radioimmunoassay (RIA) for cortisol in serum was performed.

The saline alveolar wash was stirred with an equal volume of methanol and the lipids extracted with two volumes of chloroform (Folch) [6].

The extracted lipids were plated and run on heatactivated thin layers of silica gel $\mathrm{H}$ containing 5\% ammonium sulphate. The plates were first developed upwards using chloroform-methanol-acetic acid- $\mathrm{H}_{2} \mathrm{O}(390-150-48-24 \mathrm{v} / \mathrm{v})$ then from right to left with tetrahydrofuran-methylal-methanol$2 \mathrm{NH}_{4} \mathrm{OH}(400-285-78-42 \mathrm{v} / \mathrm{v})$. Between the individual runs the plates were heated at $90^{\circ} \mathrm{C}$ for 5 minutes.

After development of the chromatograms the plates were charred at $280^{\circ} \mathrm{C}$ for 10 minutes to visualize compounds. This method allows a very good identification of lecithin, sphyngomielin, phosphatidylinositol, phosphatidylserina, phosphatidylglycerol on the plate [2].

Lecithin was eluted and phosphorus determination was performed by the method of BARTLETT [1].

\section{Results}

The P-Lecithin concentrations in lung washes of rabbits in both groups (control and treated) are shown in Fig. 1.

The level of P-Lecithin increases in both groups with gestational age, since day 27 until day 30 .

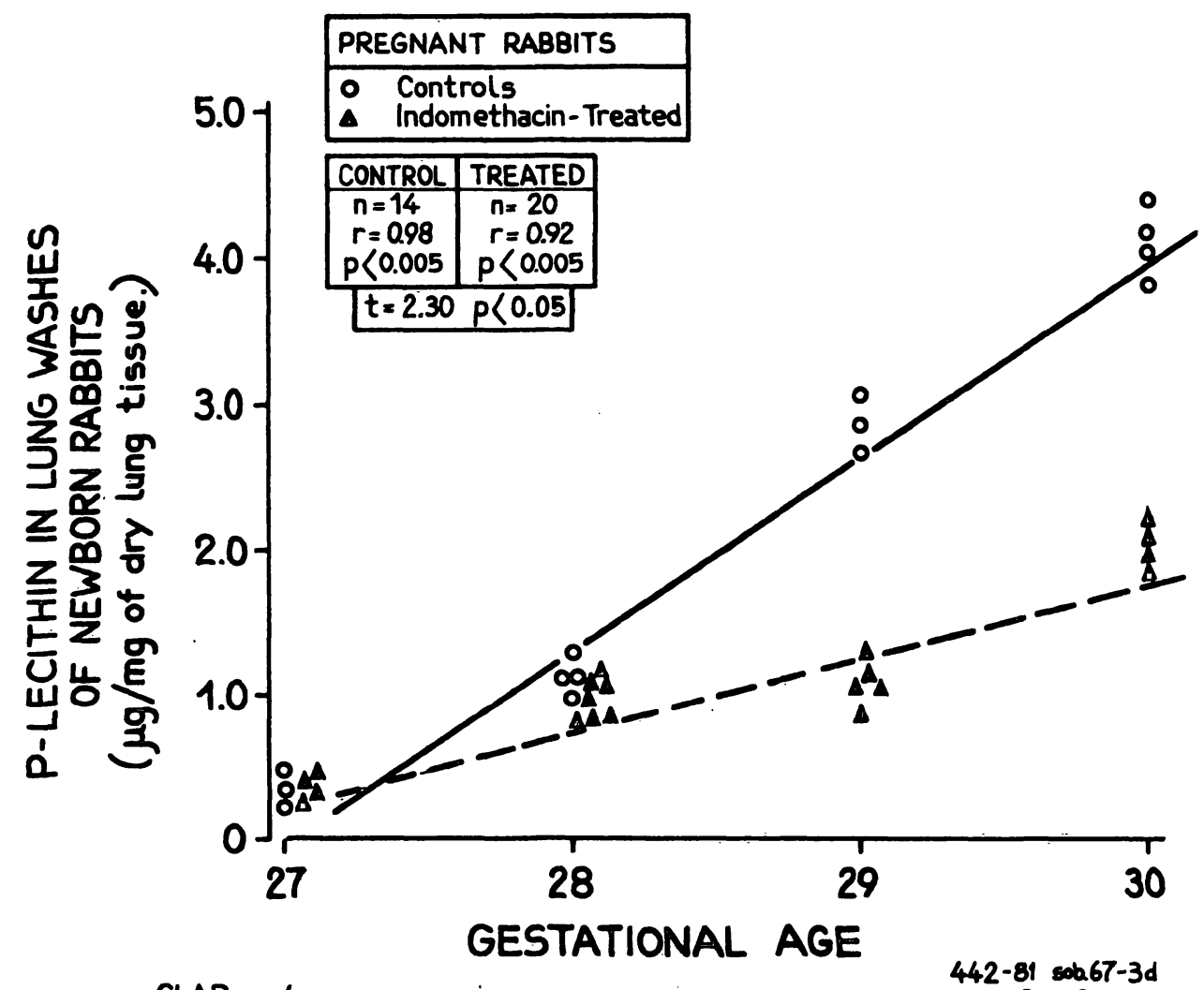

CLAP-ops/oms-Montevideo Buctos, Gusai, Belloip, Rower las.

Fig. 1. P-lecithin contents in lung washes of newborn rabbits at different gestational ages. The indomethacin-treated group has lower values at days 29 and 30 than the control group. 
Although the increment of P-Lecithin is observed in both groups, the control group has a sharp increase on day 29 , which is not seen in the Indomethacin-treated group. In the same way, on day 30 the amount of P-Lecithin in the control group is higher than the level obtained in the Indomethacin group. Lineal regression analyses were done for both groups. Their slopes were statistically different $(p<0.05)$. Mean values with standard deviations, and statistical analyses are shown on $\mathrm{Tab}$. I. These results suggest that Indomethacin in these experimental conditions produces a decrease in the amount of lecithin collected from lung washes.

The data of serum cortisol in the newborn rabbits for both groups are shown on Fig. 2 and Tab. II.

Tab. I. P-lecithin washes $\mu \mathrm{g} / \mathrm{mg}$ dry lung weight.

\begin{tabular}{|c|c|c|c|c|c|c|c|}
\hline \multirow[t]{2}{*}{ Gestational age (days) } & \multicolumn{3}{|c|}{ Control } & \multicolumn{3}{|c|}{ Treated } & \multirow{2}{*}{$\begin{array}{l}\text { Level of } \\
\text { Significance* }\end{array}$} \\
\hline & $\mathbf{n}$ & $\overline{\mathbf{x}}$ & SD & $\mathrm{n}$ & $\overline{\mathbf{x}}$ & SD & \\
\hline $\begin{array}{l}27 \\
28 \\
29 \\
30\end{array}$ & $\begin{array}{l}3 \\
4 \\
3 \\
4\end{array}$ & & $\begin{array}{l}+0.06 \\
\pm 0.10 \\
\pm 0.20 \\
\pm 0.24\end{array}$ & $\begin{array}{l}4 \\
7 \\
5 \\
4\end{array}$ & & $\begin{array}{l} \pm 0.05 \\
\pm 0.11 \\
\pm 0.14 \\
\pm 0.15\end{array}$ & $\begin{array}{l}\text { NS** } \\
\text { NS** } \\
\text { p }<0.005 \\
\text { p }<0.005\end{array}$ \\
\hline
\end{tabular}

*Student " $t$ " test

**Not significant

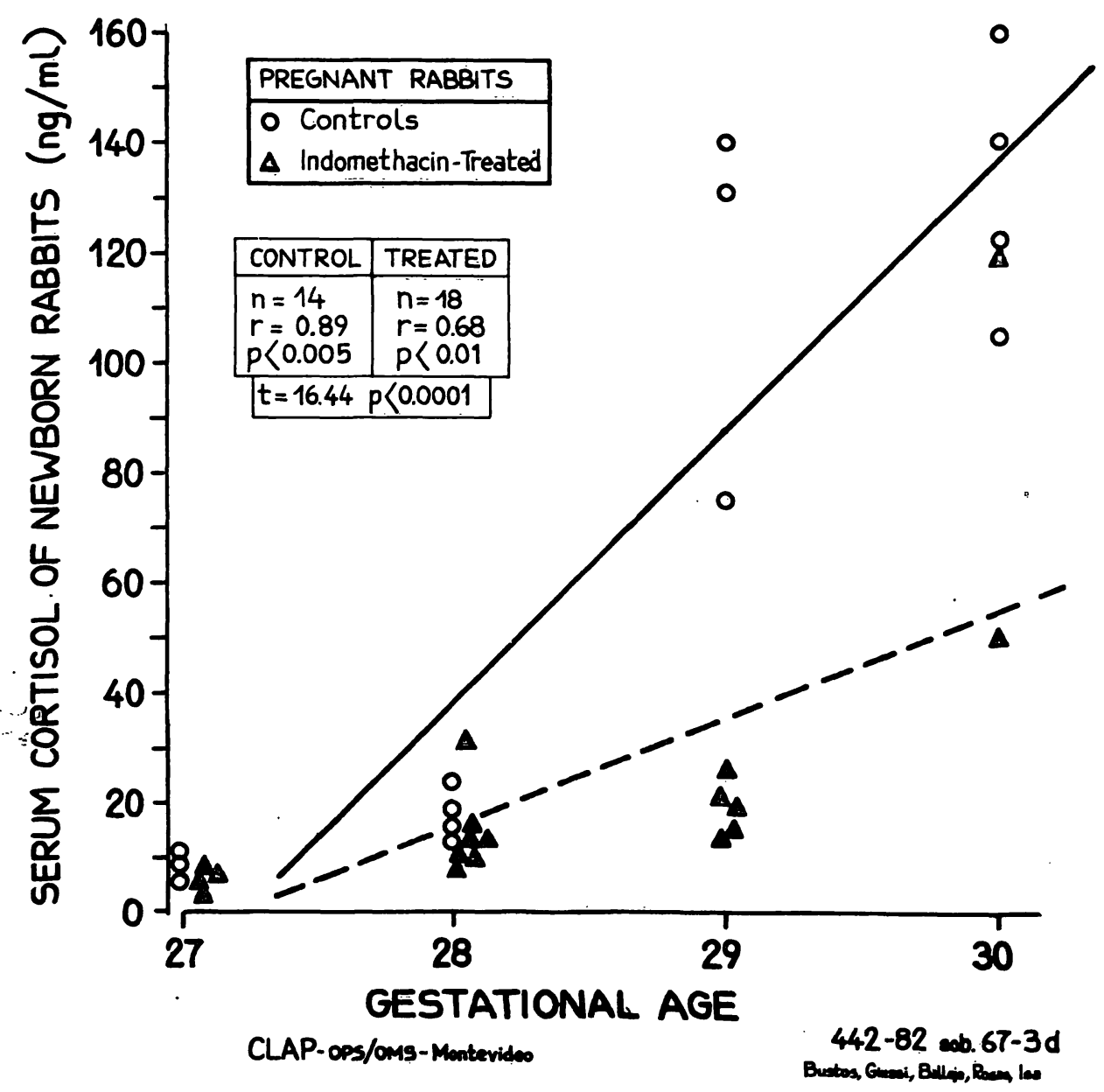

Fig. 2. Serum cortisol levels of newborn rabbits at different gestational ages. The increment of cortisol along gestational age in the indomethacin-treated group is lower than the control group. 
Tab. II. Cortisol in newborn serum ng/ml.

\begin{tabular}{|c|c|c|c|c|c|c|}
\hline \multirow[t]{2}{*}{ Gestational age (days) } & \multicolumn{2}{|c|}{ Control } & \multicolumn{3}{|c|}{ Treated } & \multirow{2}{*}{$\begin{array}{l}\text { Level of } \\
\text { Significance* }\end{array}$} \\
\hline & $\mathbf{n}$ & SD & $\mathbf{n}$ & $\overline{\mathbf{x}}$ & SD & \\
\hline $\begin{array}{l}27 \\
28 \\
29 \\
30\end{array}$ & $\begin{array}{l}3 \\
4 \\
3 \\
4\end{array}$ & $\begin{aligned} 8.26 & \pm 0.97 \\
17.7 & \pm 4.66 \\
115.6 & \pm 35.4 \\
131.75 & \pm 23.6\end{aligned}$ & $\begin{array}{l}4 \\
7 \\
5 \\
2\end{array}$ & $\begin{array}{l}5.50 \\
14.6 \\
18.5 \\
85.0\end{array}$ & $\begin{array}{l} \pm 0.83 \\
\pm 7.75 \\
\pm 4.88 \\
\pm \\
\pm 49.4\end{array}$ & $\begin{array}{l}p<0.01 \\
\text { NS** } \\
p<0.005 \\
\text { NS** }\end{array}$ \\
\hline
\end{tabular}

* Student " $t$ " test

** Not significant

Cortisol levels increase with gestational age in both groups. An important increase, six-fold at day 29, is observed in the control group, while the Indomethacin group remains at the same level obtained at days 27 and 28.

The lineal regression analysis of serum cortisol levels along gestational age of the control group and the Indomethacin-injected group shows that the slopes of both lines are statistically different $(\mathrm{p}<0.0001)$.

This indicates that Indomethacin interferes with the events that determine the levels of cortisol in fetal blood.

\section{Discussion}

Previous reports have shown that the lecithin content of the alveolar fluid correlates well with functional maturation of the lung.

To prove this, we have shown that there is a progressive increment in the lecithin content of alveolar wash with increasing gestational age. Through maternal treatment with Indomethacin, a significantly lower lecithin content in alveolar washes at 29 and 30 days of gestation is observed, indicatinganinhibition of the surfactant production.

Although there was no clear difference in the breathing pattern between both groups, it is important to point out that the reduction in the amount of lecithin found in the Indomethacin. group was less than half that of the control group.

The decreased lecithin production was associated with a diminution in the levels of serum cortisol on day 29 and 30.

The action of corticoids as inductors of surfactant is very well known [7]. Probably the lower levels of cortisol obtained on days 29 and 30 could partially explain the diminished production of lecithin observed on these same days.

The cortisol titers in fetal serum of control rabbits during the last 4 days of gestation (Tab. II and Fig. 2) show that cortisol increased abruptly on day 29 th. This fact may be due to an increased secretion of cortisol by the fetal adrenal, perhaps in response to increased secretion of ACTH by the adenohypophysis.

The lower levels of cortisol found in the Indomethacin group suggest that Indomethacin inhibited at some points of the hypothalamo-hypophysoadrenal axis, the secretion of cortisol by the fetal adrenal.

In this sense it has been published that PGs stimulates the release of hypothalamic Corticotrophin Releasing Hormone [14], ACTH from adenohypophysis $[4,8]$ and the steroidogenesis in the adrenal cortex $[5,18]$.

Also, it has been published that thyroxine stimulates the production of surfactant $[16,21]$. A recent paper demonstrated that PGs could act promoting the liberation of T4 [19].

The inhibition of surfactant production found in our experiment could also be partially explained by a reduction in $\mathrm{T} 4$ secretion.

As has been pointed out at the beginning of this paper, Indomethacin has been used as a uteroinhibitor drug. Our results advise about the possibility of an undesirable effect of Indomethacin on fetal lung maturation (inhibition of the surfactant production).

To our knowledge, this has not yet been published. Therefore we believe that other experiments should be performed before any conclusion may be extrapolated to clinical use. 


\section{Summary}

It has been suggested that premature labor is successfully treated with Indomethacin. As lung maturation is influenced by many drugs affecting metabolic processes, we investigated the effects of Indomethacin administration to pregnant rabbits upon the biochemical maturation of the fetal lung.

The rabbits were treated either with Indomethacin, $10 \mathrm{mg} / \mathrm{kg} /$ day given $\mathrm{i} / \mathrm{m}$ or solvent (placebo), $\mathrm{i} / \mathrm{m}$ at the same dose, twice daily for 3 days before the fetuses were prematurely delivered on days $27,28,29$ and 30 of gestation.

We quantified the lecithin phosphorus in alveolar washes of the newborns and cortisol levels in serum, since it has been established that endogenous glucocorticoids are essential for the biochemical development of the lung. We found that lecithin phosphorus concentration in alveolar washes increases with gestational age in the control group (Fig. 1). In the Indomethacin-treated group, lecithin phosphorus concentration also increases, but reaching lower levels than those of the control group.
This difference was greater : at days 29 and 30 , where mean values of $2.83 \mu \mathrm{g} / \mathrm{mg} \pm 0.20$ (SD) and $4.10 \mu \mathrm{g} / \mathrm{mg}$ \pm 0.24 (SD) dry lung weight respectively for the control group and $1.06 \mu \mathrm{g} / \mathrm{mg} \pm 0.14$ (SD) and $2.02 \mu \mathrm{g} / \mathrm{mg}$ \pm 0.15 (SD) for the Indomethacin-treated group were found.

Also, on all the days considered in this study, the concentration of cortisol in fetal serum of the control group was higher than that found in the treated group.

Our results indicate that the administration of Indomethacin to pregnant rabbits had a deleterious effect on the maturation of the fetal lung.

As the diminished concentration of lecithin in the alveolar washes was associated with lower levels of cortisol in fetal serum, this effect may be due in part to the inhibitory action of Indomethacin on the hypothalamo-hypophysoadrenal axis.

These results must be confirmed in other species before reaching a conclusion regarding its applicability in clinical use.

Keywords: Cortisol, fetal, indomethacin, lecithin, lung, maturation, prostaglandins, rabbits, surfactant.

\section{Zusammenfassung}

Hemmung von fetaler Lungenreifung mit Indomethacin bei schwangeren Kaninchen.

Vorzeitige Wehen können erfolgreich mit Indomethacin behandelt werden. $\mathrm{Da}$ die Lungenreifung durch manche stoffwechselaktiven Arzneimittel beeinflußt wird, erforschten wir die Wirkungen von Indomethacin-Gaben an schwangere Kaninchen auf die biochemische Reifung der fetalen Lunge.

Die Kaninchen wurden entweder mit Indomethacin (10 mg/kg/Tag i.m.) oder Lösung (placebo) i.m. in derselben Dosierung $2 \times$ täglich 3 Tage lang behandelt. Anschließend wurden die Feten frühreif am 27., 28., 29. oder 30. Tag der Schwangerschaft geboren.

Wir bestimmten den Phosphorlezithinspiegel in der alveolaren Spülflüssigkeit der Neugeborenen. Außerdem den Kortisol-Spiegel im Serum, da festgestellt worden ist, daß die endogenen Glukokortikoide wesentlich für die biochemische Entwicklung der Lunge verantwortlich sind.
Wir fanden in der Kontrollgruppe (Abb. 1), daß die Phosphorlezithinkonzentration in den alveolaren Spülflüssigkeiten anwächst mit dem Schwangerschaftsalter. In der mit Indomethacin behandelten Gruppe wird die Konzentration des Phosphorlezithin auch größer, aber sie erreicht niedrigere Spiegel als jene in der Kontrollgruppe. Dieser Unterschied war am 29. und 30. Tage größer, an denen Mittelwerte von $2,83 \mu \mathrm{g} / \mathrm{mg} \pm 0,20$ (SD) und $4,1 \mu \mathrm{g} / \mathrm{mg}$ $\pm 0,24$ (SD) trockenes Lungen-Gewicht für die Kontrollgruppe und $1,06 \mu \mathrm{g} / \mathrm{mg} \pm 0,14$ (SD) und $2,02 \mu \mathrm{g} / \mathrm{mg}$ $\pm 0,15$ (SD) für die mit Indomethacin behandelte Gruppe gefunden wurden. An allen in dieser Studie gemessenen Tagen war auch die Konzentration von Kortisol im fetalen Serum der Kontrollgruppe höher als der Spiegel in der behandelten Gruppe.

Die Ergebnisse zeigen, daß die Gabe von Indomethacin an schwangere Kaninchen eine schädliche Wirkung auf die Reifung der fetalen Lunge hat.

Schlüsselwörter: Fet, Indomethacin, Kortisol, Lezithine, Lungenreifung, Prostaglandine, Surfactant.

\section{Résumé}

Inhibition de la maturation pulmonaire foetale par indométhacine chéz les lapins gravides

Ayant entendu parler d'un traitement réussi du travail prématuré par indométhacine et sachant quela maturation pulmonaire est influencée par bien des médicaments affectant les processus métaboliques, nous avons décidé d'étudier les effets de l'indométhacine sur la maturation biochimique du poumon foetal chez des lapins gravides. Les lapins ont reçu soit de l'indométhacine, $10 \mathrm{mg} / \mathrm{kg} /$ jour $\mathrm{i} / \mathrm{m}$, ou un solvant (placebo), $\mathrm{i} / \mathrm{m}$ avec la même dose, deux fois par jour pendant les trois jours précédant l'ac- couchement prématuré des foetus le $27,28,29$ ou 30 ème jour de gestation.

Sachant que les glucocorticoides endogènes sont indispensables pour le développement biochimique du poumon, nous avons déterminé la quantité de lécithine phosphoreuse dans les lavages alvéolaires des nouveauxnés et les niveaux de cortisol dans le sérum.

Nous avons pu établir que la concentration de lécithine phosphoreuse dans les lavages alvéolaires augmente avec l'âge de gestation dans le groupe de contrôle (Fig. 1). Dans le groupe traité à l'indométhacine, la concentration 
de lécithine phosphoreuse a aussi augmenté mais à des degrés moindres, la différence ayant été plus accusée aux 29 et 30 èmes jours où les valeurs moyennes ont été respectivement de $2,83 \mu \mathrm{g} / \mathrm{mg} \pm 0,20$ (SD) et de 4,10 $\mathrm{\mu g} / \mathrm{mg} \pm 0,24$ (SD) de poids pulmonaire sec pour le groupe de contrôle et de $1,06 \mu \mathrm{g} / \mathrm{mg} \pm 0,14$ (SD) et de $2,02 \mu \mathrm{g} /$ $\mathrm{mg} \pm 0,15$ (SD) pour le groupe traité à l'indométhacine. En conclusion, on peut dire que pour tous les jours pris en considération dans notre étude, la concentration de cortisol dans le sérum foetal du groupe de contrôle a été plus élevée que celle relevée dans le groupe traité à l'indométhacine.
Ces résultats indiquent que l'administration d'indométhacine à des lapins gravides produit un effet délétère sur la maturation du poumon foetal.

Etant donné que la réduction de la concentration de lécithine dans les lavages alvéolaires se double d'une baisse des niveaux de cortisol dans le sérum foetal, l'effet précité est peut-être dû en partie à l'action inhibitrice de l'indométhacine sur l'axe hypothalamo-hypophyso-adrénal.

En considération de tous ces résultats, il s'avère indispensable de procéder à d'autres investigations avant de tirer une conclusion applicable sur le plan clinique.

Mots-clés: Cortisol, foetal, indométhacine, lapins, lécithine, maturation, poumon, prostaglandine, surfactant.

\section{Bibliography}

[1] BARTLETT, G. R.: Phosphorous assay in column chromatography. J. Biol. Chem. 234 (1959) 466

[2] BUSTOS, R., M. V. KULOVICH, L. GLUCK: Significance of Phosphatidyl Inositol and Phosphatidylglycerol in amniotic fluid of complicated pregnancies. Clin. Res. 24 (1976) 191 A

[3] DE LEMOS, R. A., D. W. SHERMETA, I. H. KNELSON, R. KOTAS, M. E. AVERY: Acceleration of appearance of pulmonary surfactant in the fetal lamb by administration of corticosteroids. Amer. Rev. Resp. Dis. 102 (1970) 454

[4] DE WIED, D., A. WITTER, D. H. G. VERSTEEG, A. H. MULDER: Release of ACTH by substances of CNS origin. Endocrinology 85 (1969) 561

[5] FLACK, I. D., R. JESSUP, P. W. RAMWELL: Prostaglandin stimulation of rat corticosteroidogenesis. Science 163 (1969) 691

[6] FOLCH, J., M. LEES, G. H. SLOANE-STANLEY: A simple method for the isolation and purification of total lipids from animal tissues. J. Biol. Chem. 226 (1957) 497

[7] HALlMAN, M., L. GLUCK: Development of fetal lung. J. Perinat. Med. 5 (1977) 3

[8] HEDGE, G. A., S. D. HANSON: The effects of prostaglandins on ACTH secretion. Endocrinology 91 (1972) 925

[9] KARIM, S. M. M., I. DEVLIN: Prostaglandin content of amniotic fluid during pregnancy and labor. $J$. Obstet. Gynaec. Brit. Cwlth. 74 (1967) 230

[10] KARIM, S. M. M.: Appearance or prostaglandin $\mathrm{F}_{2}$ $\alpha$ in human blood during labor. Brit. med. J. 4 (1968) 618

[11] KARIM, S. M. M., R. R. TROUSSEL, K. HILlIER, R. C. PATEL: Induction of labor with prostaglandin $F_{2} \alpha$. J. Obstet. Gynaec. Brit. Cwlth. 76 (1969) 769

[12] LIGGINS, G. C., R. N. HowIE: A controlled trial of antepartum glucocorticoid treatment for prevention of the respiratory distress syndrome in premature infants. Pediatrics 50 (1972) 515

[13] MOTOYAMA, K. K., M. M. ORZALESI, Y. KIKKAWA, M. KAIBARA, B. WU, C. J. ZIGAS, C. D. COOK: Effect of cortisol on the maturation of fetal rabbit lungs. Pediatrics 48 (1971) 547

[14] PENG, T. C., K. M. SIX, D. L. MUMSON: Effects of PGE 1 on the hypothalamo-hypophyseal-adrenocortical axis in rats. Endocrinology 86 (1970) 202

[15] Platz KER, A. C. G., J. A. KITTERMAN, E. J, MESCHER, J. A. ClementS, W. H. TOOLEY: Surfactant in the lung and tracheal fluid of the fetal lamb and acceleration of its appearance by dexamethasone. Pediatrics 56 (1975) 554

[16] REDDING, R. A., W. H. J. DOUGLAS, M. STEIN: Thyroid hormone influence upon lung surfactant metabolism. Science 175 (1975) 994

[17] ROTH BRANDEL, V., M. BYGDEMAN, V. WIDQUIVIST: Prostaglandin for induction of therapeutic abortion. Lancet 1 (1970) 190

[18] SARITA, T., N. N,KAPLAN : Adrenal steroidogenesis: the effects of prostaglandins. J. Clin. Invest. 51 (1972) 2246

[19] THOMPSON, M. E., G. P. OREZYK, O. A. HEDGE: In vivo inhibition of thyroid secretion by indomethacin. Endocrinology 100 (1977) 1060

[20] VANE, J. R.: Prostaglandins and Aspirin-Like Drugs. Hosp. Pract. 7 (1972) 61

[21] WU, B., Y. KAKKAWA, M. M. ORZALESI, E. K. MOTOYAMA, M. KaIBARA, C. J. ZIGAS, C. D. COOK: The effect of thyroxine on the maturation of fetal rabbit lungs. Biol. Neonat. 21 (1972) 541

[22] ZUCKERMAN, H., V. REISS, I. RUBINSTEIN: Inhibition of human premature labor by indomethacin. Obstet. and Gynec. 44 (1974) 787

Received September 4, 1977. Accepted January 9, 1978.

Dr. Raúl Bustos

Casilla de correo 627

Montevideo, Uruguay 